\title{
Revisão por pares: crise de demanda ou mudança de valores?
}

O sistema de revisão por pares é a forma mais empregada para a análise de textos científicos. Parte do pressuposto que o mérito acadêmico daquela obra será analisado por integrantes da mesma comunidade intelectual, de forma desinteressada, e, geralmente anônima. O parecerista faz a revisão por razões distintas da lógica do ganho econômico, destacando-se: um senso de vinculação a uma comunidade; um exercício de poder acadêmico; o desfrute de acesso privilegiado ao debate; e por esperar reciprocidade. Esse exercício de doação individual e cooperação altruísta aos interesses comuns da comunidade científica também faz parte de um certo ethos assumido por esta comunidade.

Por suas características, a prática da revisão por pares se aproxima do que a vertente antropológica maussiana denomina de dom ritual, um sistema de trocas que se alicerça na tríade dar-receber-retribuir. Esse sistema, mais do que fazer circular dádivas, materializadas como bens ou serviços, estabelece vínculos (de amizade ou de rivalidade), obrigações e dívidas ético-morais. A dádiva ofertada ao outro estabelece a oportunidade deste também exercitar o dom, demarcando um pertencimento àquela rede de sociabilidade e uma afirmação de sua persona.

A revisão por pares é essencial para se produzir ciência de qualidade. Revisar artigo é atividade científica. A reputação de um pesquisador se constrói não só pela qualidade dos seus artigos, mas também pela qualidade da sua revisão nos textos dos pares. No sistema de valores da comunidade científica, a recusa sistemática de revisões pelo pesquisador é negativa. Todavia, encontrar revisores para os inúmeros artigos que chegam tem sido um problema crescente para os editores. Notável também a diminuição da qualidade das revisões.

Algumas opções de contornar essa crise podem ser apontadas, tais como: indicar recém-formados de Mestrado e Doutorado; minimizar as "oportunidades perdidas" de cadastrar revisores; proceder a um cadastramento compulsório dos autores quando da submissão de novos artigos para publicação; incentivar que os autores indiquem revisores.

Por outro lado, torna-se imperativa a necessidade de que, no julgamento dos pedidos de financiamento e de bolsa ao CNPq, assim como na avaliação da pós-graduação realizada pela Capes, sejam incorporadas nos critérios de avaliação a quantidade e a qualidade das revisões feitas pelo pesquisador.

Além das sugestões de enfrentamento do problema, questionamos: o que explicaria essa crise do sistema de avaliação por pares? As regras vigentes de análise de mérito acadêmico orientadas por parâmetros de um produtivismo intelectual que valoriza mais certa atividade (publicação) e atribui menor valor a outras, contribuiria para a adoção de um cálculo utilitarista de emprego do tempo? Se afirmativo, podemos pressupor estarmos diante de uma mudança em marcha do ethos acadêmico? Agora priorizando os melhores resultados individuais, apostando que a soma destes sucessos trará o melhor desenvolvimento à coletividade e à ciência. Ou estaríamos diante do esgotamento das energias deste ciclo de produtivismo? Se para cada artigo precisamos de dois ou três pareceristas para avaliá-lo, qual será a capacidade de prover tal demanda? Haverá algo errado com a nossa maneira de fazer ciência e com o uso do nosso tempo? Estaríamos vivendo a miragem do mais é melhor?

No confronto entre os valores, regras institucionais e crenças que definem as ações de nossa(s) comunidade(s) científica(s) perguntamos: que tipos de trocas e vínculos queremos?

Suely F. Deslandes

Instituto Nacional de Saúde da Mulher, da Criança e do Adolescente Fernandes Figueira, Fundação Oswaldo Cruz, Rio de Janeiro, Brasil.

deslandes.s@gmail.com
Antônio Augusto Moura da Silva

Centro de Ciências da Saúde, Universidade Federal do

Maranhão, São Luís, Brasil.

aamouradasilva@gmail.com 